\title{
Preliminary data on chronic effects of ultraviolet radiation on the growth of some phytoplankton species of the Beagle Channel, Argentina*
}

\author{
MARCELO P. HERNANDO and NEMESIO A. SAN ROMÁN \\ CADIC-CONICET, 9410 Ushuaia, Tierra del Fuego, Argentina. E-mail: Hernando@infovia.com.ar
}

\begin{abstract}
SUMMARY: Serious concerns exist that the thinning of stratospheric ozone and the resulting enhancement in the solar UVB radiation, may impair marine primary productivity. Also, UVB may alter food web dynamics and food availability for higher trophic levels in marine ecosystems inducing changes in phytoplankton species composition. The main goal of this study was to examine the responses of different species of marine phytoplankton to solar UVR. Specifically, we compared the UV sensitivity of a phytoplankton natural community isolated from the Beagle Channel (54 $52^{\prime} \mathrm{S}, 68^{\circ} 18^{\prime} \mathrm{W}$, Ushuaia, Argentina), as well as the response of two taxa which were isolated from that community (i.e., a pennate diatom, Navicula sp., and a phytoflagellate pertaining to the Class Cryptophyceae) to UV radiation. Exposure to UVB or UVA radiation treatments had no significant effects $(\mathrm{p}>0.05)$ on exponential growth rate in Navicula sp. However, when the phytoflagellate [Class Cryptophyceae] was exposed to UVB, the growth rate in the exponential phase was inhibited significantly $(\mathrm{p}<0.01)$ compared with the PAR control. Marked changes in the relative abundance of the main taxonomic groups were observed in the community cultures: the relative abundance of phytoflagellates was significantly lower after exposure to the UVB treatment than after exposure to the PAR treatment $(p<0.05)$. However, the percentage of centric diatoms increased significantly $(\mathrm{p}<0.05)$ when they were exposed to UVB. The growth rate at the end of the exponential phase of growth of the community was inhibited significantly $(\mathrm{p}<0.01)$ when the algae were exposed to UVB and UVA.
\end{abstract}

Key words: Ultraviolet radiation, inhibition, phytoflagellates, diatoms, growth rate

RESUMEN: DATOS PRELIMINARES SOBRE LOS EFECTOS CRÓNICOS DE LA RADIACIÓN ULTRAVIOLETA EN LA DINÁMICA POBLACIONAL DE ESPECIES FITOPLANCTÓNICAS DEL CANAL DEL BEAGLE, ARGENTINA. - Existe una gran preocupación por los efectos que podría ocasionar un aumento de la radiación ultravioleta (en especial UVB, $280-320 \mathrm{~nm}$ ) por la disminución de la capa de ozono, sobre los ecosistemas acuáticos. Con el fin de estudiar la sensibilidad de algunas especies fitoplanctónicas del Canal del Beagle (54 $52^{\prime} \mathrm{S}, 68^{\circ} 18^{\prime} \mathrm{W}$, Ushuaia, Argentina) a la radiación solar natural, se utilizaron cultivos monoespecíficos de un fitoflagelado (Clase: Cryptophyceae) y una diatomea (Navicula sp.) para determinar efectos a largo plazo (días) en la fase exponencial de sus tasas de crecimiento. Considerando la importancia de la composición específica en relación a la dinámica de la cadena alimentaria y la subsecuente reserva de alimento disponible para los niveles tróficos superiores en el ecosistema marino, también se incluyó la respuesta de la comunidad en su conjunto. No se observaron efectos significativos ( $>0.05$ ) en la tasa de crecimiento exponencial cuando Navicula sp. fue expuesta a UVB ó UVA (320-400 nm). Sin embargo, cuando los fitoflagelados [Clase Cryptophyceae] fueron expuestos a UVB, su tasa de crecimiento fue inhibida significativamente $(\mathrm{p}<0.01)$. Al exponer a la comunidad fitoplanctónica se observaron cambios en la abundancia relativa de las especies. El porcentaje de fitoflagelados fue significativamente menor $(\mathrm{p}<0.05)$ al ser expuestos a UVB comparado con PAR $(400-700 \mathrm{~nm})$. El porcentaje de diatomeas céntricas, en cambio, aumentó significativamente $(\mathrm{p}<0.05)$. No se observaron diferencias significativas entre los diferentes días de exposición ni entre tratamientos en la respuesta de las diatomeas pennadas. El crecimiento exponencial de la comunidad fue inhibido significativamente $(\mathrm{p}<0.01)$ cuando las algas fueron expuestas a UVB y UVA.

Palabras clave: Radiación ultravioleta, inhibición, fitoflagelados, diatomeas, tasa de crecimiento. 


\section{INTRODUCTION}

It has been demonstrated that radiation in the ultraviolet middle region (UVB, 280-320 nm) penetrates down into the ecologically relevant depths of the ocean (Smith and Backer, 1979, 1981; Mitchell, 1990; Holm-Hansen et al., 1993). Several studies showed that both UVB and UVA (320-400 nm) might have inhibitory effects on primary productivity of lakes and oceans (Steemann Nielsen, 1964; Helbling et al., 1992; Smith et al., 1992; Cullen et al., 1992; Jitts et al., 1976; Holm-Hansen et al., 1993). Interest in this subject increased during recent years due to the spring reduction in the stratospheric ozone layer observed at the Polar vortex above the Antarctic Continent. It was suggested that this phenomenon may enhance the negative effects of the ultraviolet radiation (UVR) in the pelagic oceanic communities. This can be explained by the differential absorption of UVR by ozone, which results in an increase of UVB when the ozone layer decreases (Watson, 1988; Lubin et al., 1989; Blumthaler and Ambach, 1990). Some important studies on the phytoplanktonic communities and the long-term effects of exposure to UV radiation have been made in Antarctic waters (Karentz et al., 1991; Villafañe et. al., 1995; Davidson and Marchant, 1994). Those studies concluded that there is a large range of differential tolerance to UVB and UVA by different taxa. Some species were not adversely affected by the exposure to the spectrum of wavelengths. This differential tolerance may be an active parameter in the separation of species niches, and the expected increase in UVB radiation could make predictions about the responses at the ecosystem level more complex. Given that UVA radiation plays a key role in triggering DNA repair mechanisms (Friedberg, 1985), both UVA and UVB effects need to be considered in experimental studies. As a consequence, to understand the possible impact of ozone-related enhanced levels of UVB on phytoplankton in the southern ocean, it is necessary to increase our knowledge of the biological significance of both UVB and UVA.

Most of the studies on the Antarctic continent were conducted as short-term experiments (HolmHansen et al., 1993; Helbling et al., 1994; Smith et $a l ., 1992)$, only a few were done with monospecific cultures (Karentz et al., 1991; Villafañe et. al., 1995; Davidson and Marchant, 1994). More information is necessary in order to understand the long-term responses caused by the exposure to UVR and the reaction of algae to the new conditions of increased UVB in Subantarctic waters.

The main goal of this work was to study the longterm (growth rate scale, days) effects of UVB and UVA on phytoplankton from Subantarctic waters. The basis for our concern is that although the decrease in ozone concentration is mainly produced in the Polar vortex above the Antarctic Continent, the so-called "ozone hole" is a dynamic system which can also be found in the south of the American continent (Orce et al., 1995).

\section{MATERIAL AND METHODS}

The experiments were carried out in Ushuaia (545'스. $68^{\circ} 18^{\prime} \mathrm{W}$, Tierra del Fuego, Argentina), using phytoplankton from the Beagle Channel (Fig. 1). Surface water samples were collected approximately at the center of the Channel (Fig. 1, point A) using a five-litre Niskin bottle with a spring covered with Teflon. The two experiments with monospecific cultures lasted from 21 to 29 January 1997, while those involving the whole phytoplankton community lasted from 4 to 9 December 1996.

The samples (from local populations or from monospecific cultures) were exposed to the natural solar radiation in wood incubators (shaking twice a day) within a temperature controlled bath $\left(10^{\circ} \mathrm{C}\right)$, insuring that the cultures were irradiated from every side.

Cylindrical UV-transparent vessels $(500 \mathrm{ml})$, allowing the passage of ultraviolet $\mathrm{B}$ radiation (UVB, 280-320 nm) + ultraviolet A radiation (UVA, 320-400 nm) + Photosynthetically Available Radiation (PAR, 400-700 nm) were used for full exposure of phytoplankton to natural radiation (UVB treat-

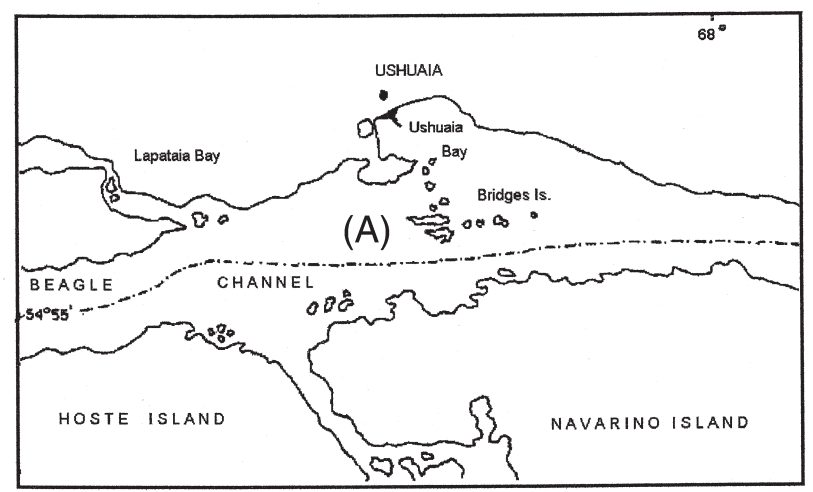

FIG. 1. - Map with station location (A) in the Beagle Channel, Ushuaia, Argentina. 
ment). Pre-filter Mylar was added to these bottles for the UVA treatment (UVA+PAR). For the PAR controls, cylindrical plexiglass vessels $(500 \mathrm{ml}$ capacity) were used. Three replicate samples were considered for each of the treatments and controls.

The chlorophyll-a (chl-a) analyses were made by filtering water through Whatman glass fibre filters (GF/F, $25 \mathrm{~mm}$ diameter) followed by the extraction of pigments in absolute methanol (Holm-Hansen and Riemann, 1978). The concentrations of chl-a were calculated fluorimetrically (Holm-Hansen et al., 1965) using a Turner fluorometer (model 450).

Subsamples of each treatment from all the experiments were taken daily at 9:00 am for determinations of the phytoplankton's specific composition (aliquots of all treatments were kept in dark bottles and fixed with formalin neutralized with borate of sodium, final concentration $0.4 \%$ ). The cell concentration in the subsamples from the monospecific cultures was calculated using a hematocymeter with Neubauer camera, following Villafañe and Reid (1995). All the samples of the community were counted by the Utermöhl method. Navicula $s p$. and a phytoflagellate (Class Cryptophyceae) were isolated from the natural community and kept in the laboratory under controlled temperature conditions (10 $\left.{ }^{\circ} \mathrm{C}\right) . \mathrm{F} / 2$ culture medium was added to the diatom strain (Guillard and Ryther, 1962), whereas for the case of the phytoflagellate the same medium was used but without the addition of silicate. No nutrients were added to the experimental containers during the course of the experiments. The cultures were grown under artificial light conditions (three $40 \mathrm{~W}$ Osram fluorescent lamps, 12:12 light, darkness) before exposure to the natural radiation. Incident solar radiation was monitored continuously using a spectroradiometer (Model GUV 511; Biospherical Instruments, Inc.) which recorded irradiance at four wavelengths in the UV range $(305,320,340,380$ $\mathrm{nm})$, and PAR every minute.

The following equation was used to determine specific growth rate constant:

$\mathrm{K}=\mathrm{Ln}(\mathrm{N} 1 / \mathrm{N} 0) / \mathrm{t} 1$

where: $\mathrm{t} 1$ is the time of measurement, $\mathrm{N} 1$ is the concentration of cells at time $\mathrm{t} 1, \mathrm{~N} 0$ is the initial concentration of cells.

A multifactor ANOVA (Tukey test) was used to test the significance of the differences observed between the exponential phase of the growth rate in each treatment with respect to the exponential phase of the PAR controls. Days of exposure and treatments were used as factors. When the interaction
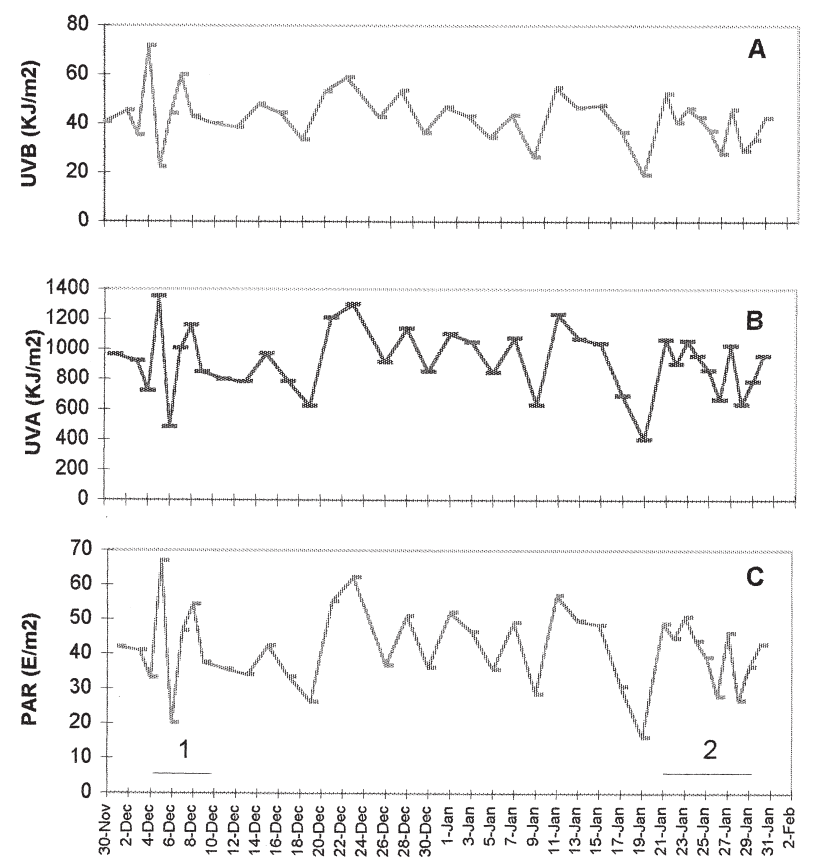

FIG. 2. - Variations in UVR doses and PAR doses at the Beagle Channel from December 1 to January 31, 1997. The time spans of our two experiments are indicated in (C): (1) Experiment with the community and (2) Experiment with monospecific cultures. (A) UV-B doses (280-320 nm), in $\mathrm{kJ} / \mathrm{m}^{2}$; (B) UV-A (320-400 nm), in $\mathrm{kJ} / \mathrm{m}^{2}$; (C) PAR $(400-700 \mathrm{~nm})$ in $\mathrm{E} / \mathrm{m}^{2}$.

was significant, one-way ANOVA was used for the analysis (Neter and Wasserman, 1974). The arcsin transformation was applied to correct the continuity of the respective percentages. The same statistical procedures were used in the analyses of the relative abundance of the main taxonomic groups in the community (pennate and centric diatoms and phytoflagellates). In all cases the exponential phase of the growth rate of PAR treatment was taken as control.

\section{RESULTS}

Data in Figure 2 show the variation of surface daily doses of UVB, UVA and PAR throughout the study period (Orce et al., 1997). During the period of experiment with natural populations (1), the average daily doses from 4 to 9 December of 1996, were: $46.08 \mathrm{~kJ} / \mathrm{m}^{2}$ for UVB (Fig. 2A), $930.6 \mathrm{~kJ} / \mathrm{m}^{2}$ for UVA (Fig. 2B) and $43.15 \mathrm{E} / \mathrm{m}^{2}$ for PAR (Fig. 2C). During the period of experiment with monospecific cultures (2), the average daily doses from, 21 to 29 January of 1997 were: $39.55 \mathrm{~kJ} / \mathrm{m}^{2}$ for UVB (Fig. 2A), $885.39 \mathrm{~kJ} / \mathrm{m}^{2}$ for UVA (Fig. 2B) and 40.61 $\mathrm{E} / \mathrm{m}^{2}$ for PAR (Fig. 2C). The variability noted in the 
TABLE 1. - Effect of treatment and day on the growth (mean +/- SE using cell number per millilitre) of Community, Navicula sp. and Phytoflagellates during the exponential phase of the growth rate. Note: For each factor, the differences are significant at $\mathrm{p}<0.05(*)$ or $\mathrm{p}<0.01$ (**) (Tukey test). Since the interaction regarding phytoflagellates was significant, the factor "day" was analyzed by One-Way ANOVA. The factor "treatment" represents algae which received UVB + UVA + PAR radiation; UVA those exposed to $\mathrm{UVA}+\mathrm{PAR}$ and PAR those exposed to PAR. The factor "day" represents the exposure days to different treatments.

\begin{tabular}{lcc}
\hline & Navicula $\mathbf{s p .}$ & \\
Factors & $F$ & Sign. level \\
\hline Treatment & 2.77 & 0.08 \\
Day & 22.35 & $* *$ \\
Interaction & 0.728 & 0.63 \\
\hline
\end{tabular}

\begin{tabular}{lrc}
\hline & Average & Homog. group \\
\hline Treatment & $0.27 \pm 0.07$ & $*$ \\
UVA & $0.32 \pm 0.11$ & $*$ \\
UVB & $0.41 \pm 0.06$ & $*$ \\
PAR & & $*$ \\
Day & $0.006 \pm 0.08$ & $*$ \\
1 & $0.33 \pm 0.05$ & $* *$ \\
2 & $0.40 \pm 0.03$ & $*$ \\
4 & $0.59 \pm 0.02$ & \\
\hline
\end{tabular}

\begin{tabular}{lcc}
\hline & Community & \\
Factors & $F$ & Sign. level \\
\hline Treatment & 21.91 & $* *$ \\
Day & 8.584 & $* *$ \\
Interaction & 3.087 & 0.06 \\
\hline
\end{tabular}

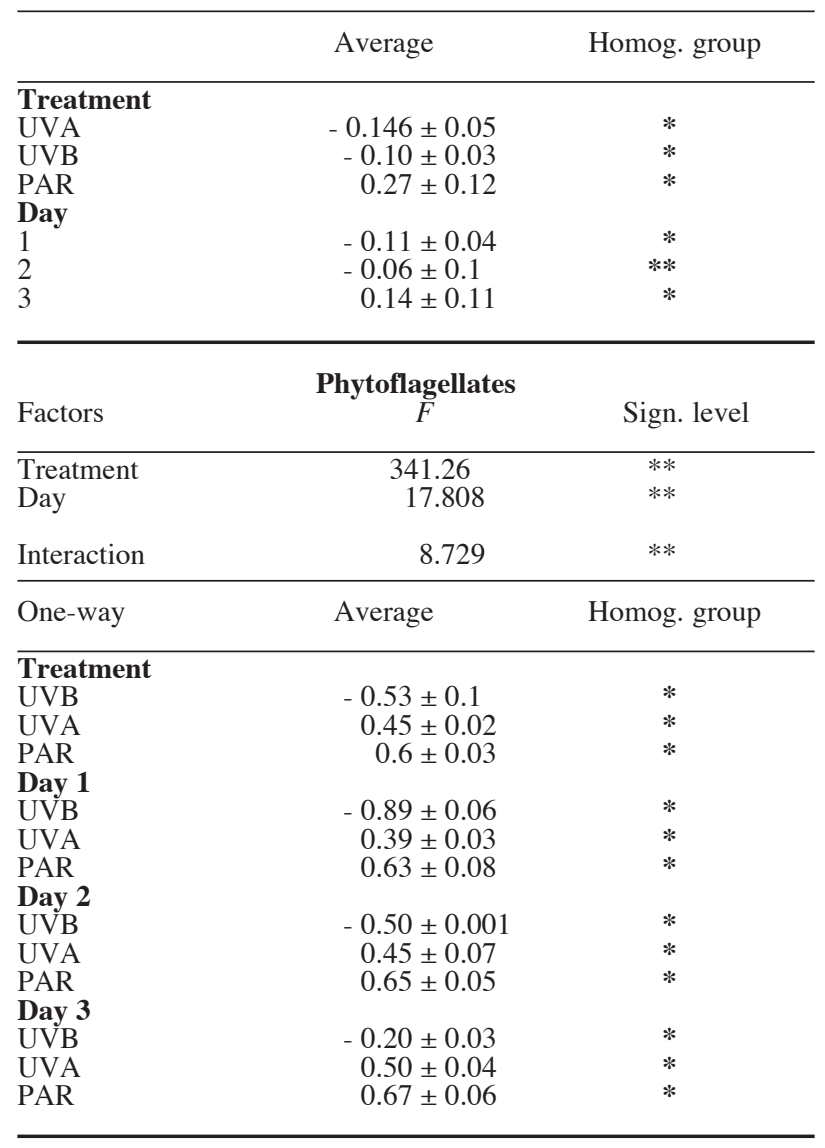

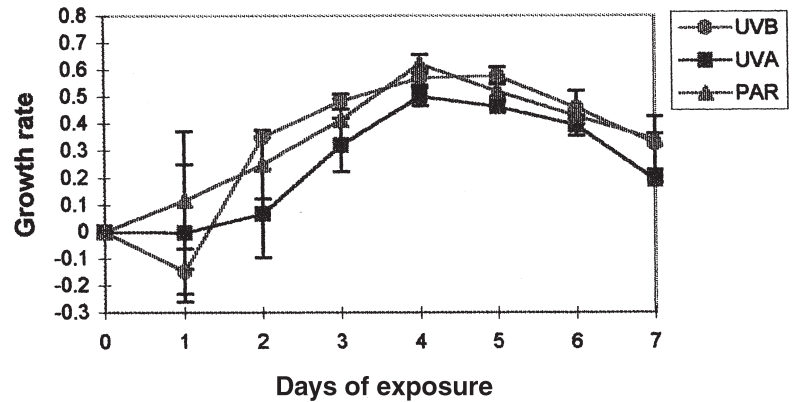

FIG. 3. - Growth rate using cell number of Navicula sp. per millilitre when exposed to the natural solar radiation as a function of the exposition days. UVB represents those algae exposed to UVB + UVA + PAR, UVA those exposed to UVA + PAR and PAR, those exposed to PAR. Each point represents the mean with the standard deviation.

data is due primarily to changes in the degree of cloud cover.

\section{Experiment with monospecific cultures}

The specific growth rate $(\mathrm{K})$ corresponding to the different treatments of the Navicula $s p$. are shown in Figure 3. There were no significant differences $(p>0.05)$ between treatments (Table 1$)$. At day 4 of exposure, $\mathrm{K}$ values were significantly higher $(\mathrm{p}<0.01)$ than those calculated for the first day of the experiment (Table 1).
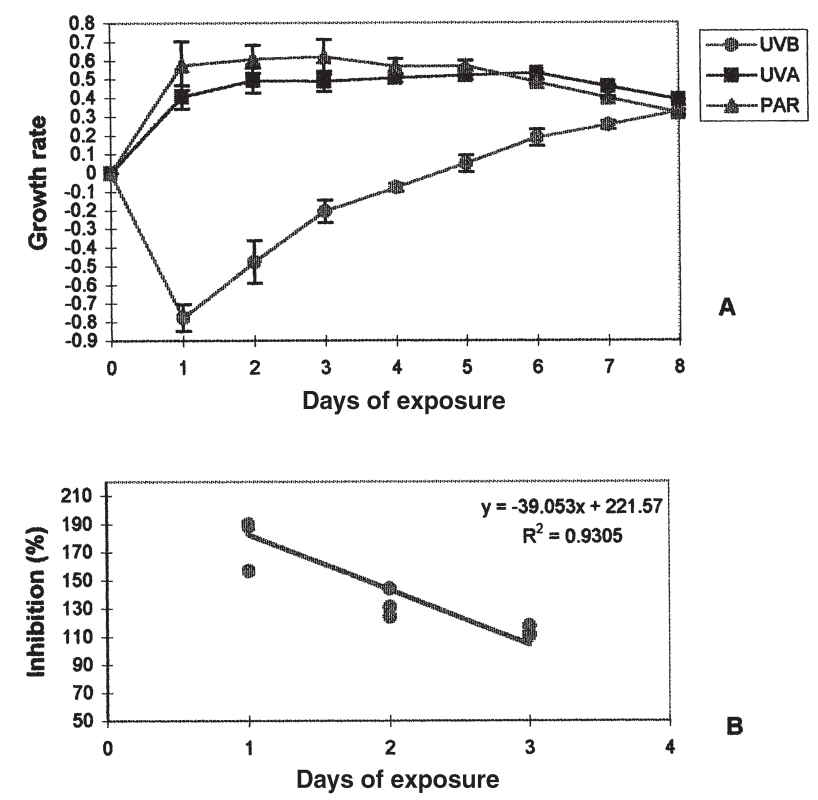

FIG. 4. - Experiences with phytoflagellates. (A), Growth rate using cell number when exposed to the natural solar radiation as a function of the exposition days. UVB represents those algae exposed to UVB + UVA + PAR, UVA those exposed to UVA + PAR and PAR, those exposed to PAR. (B), Percentage of inhibition produced by UVB during the increase in the exponential phase of growth with regard to PAR control. Each point represents the mean with the standard deviation. 
TABLE 2. - Mean values of chlorophyll-a $\left(\mathrm{mg} / \mathrm{m}^{3}\right) \pm \mathrm{SE}$, as a function of days of exposure when exposed to UVB (UVB + UVA + PAR); UVA (UVA+PAR) and PAR for: Phytoflagellates, Navicula sp. and Community.

\begin{tabular}{|c|c|c|c|}
\hline \multirow[b]{2}{*}{$\begin{array}{l}\text { Exposition } \\
\text { days }\end{array}$} & \multicolumn{3}{|c|}{ Phytoflagellates } \\
\hline & UVB & UVA & PAR \\
\hline 0 & $0.74 \pm 0.05$ & $0.60 \pm 0.00$ & $0.80 \pm 0.13$ \\
\hline 1 & $0.34 \pm 0.01$ & $0.90 \pm 0.06$ & $1.40 \pm 0.05$ \\
\hline 2 & $0.29 \pm 0.05$ & $1.62 \pm 0.22$ & $2.66 \pm 0.09$ \\
\hline 3 & $0.40 \pm 0.05$ & $2.61 \pm 0.42$ & $5.08 \pm 0.63$ \\
\hline 4 & $0.54 \pm 0.05$ & $4.56 \pm 0.42$ & $7.62 \pm 0.18$ \\
\hline 5 & $0.97 \pm 0.26$ & $8.06 \pm 0.95$ & $13.71 \pm 0.97$ \\
\hline 6 & $2.34 \pm 0.71$ & $14.49 \pm 0.12$ & $14.57 \pm 2.93$ \\
\hline 7 & $4.40 \pm 0.94$ & $14.92 \pm 0.73$ & $12.91 \pm 2.58$ \\
\hline 8 & $10.22 \pm 3.21$ & $13.20 \pm 0.01$ & $10.11 \pm 1.95$ \\
\hline
\end{tabular}

\begin{tabular}{|c|c|c|c|}
\hline $\begin{array}{l}\text { Exposition } \\
\text { days }\end{array}$ & \multicolumn{3}{|c|}{ Navicula sp. } \\
\hline $\begin{array}{l}0 \\
1 \\
2 \\
3 \\
4 \\
5 \\
5 \\
6 \\
7\end{array}$ & $\begin{array}{r}0.86 \pm 0.00 \\
0.79 \pm 0.03 \\
1.50 \pm 0.06 \\
3.39 \pm 0.18 \\
7.97 \pm 1.22 \\
13.53 \pm 0.66 \\
12.37 \pm 1.90 \\
8.23 \pm 7.03\end{array}$ & $\begin{array}{r}2.83 \pm 0.15 \\
2.69 \pm 0.51 \\
3.25 \pm 1.04 \\
7.44 \pm 2.32 \\
20.03 \pm 2.57 \\
30.31 \pm 5.04 \\
32.09 \pm 3.99 \\
10.89 \pm 0.61\end{array}$ & $\begin{array}{r}1.53 \pm 0.47 \\
1.70 \pm 0.58 \\
2.64 \pm 1.12 \\
5.63 \pm 2.00 \\
19.87 \pm 1.87 \\
20.80 \pm 2.96 \\
21.08 \pm 2.68 \\
17.03 \pm 4.14\end{array}$ \\
\hline $\begin{array}{l}\text { Exposition } \\
\text { days }\end{array}$ & UVB & $\begin{array}{r}\text { mmunity } \\
\text { UVA }\end{array}$ & PAR \\
\hline $\begin{array}{l}0 \\
1 \\
2 \\
3 \\
4 \\
5\end{array}$ & $\begin{array}{l}3.00 \pm 0.00 \\
1.21 \pm 0.17 \\
0.41 \pm 0.12 \\
0.97 \pm 0.32 \\
1.65 \pm 0.27 \\
3.40 \pm 0.59\end{array}$ & $\begin{array}{l}3.00 \pm 0.00 \\
1.03 \pm 0.24 \\
0.86 \pm 0.21 \\
1.47 \pm 0.06 \\
2.94 \pm 0.71 \\
5.06 \pm 0.97\end{array}$ & $\begin{array}{l}3.00 \pm 0.00 \\
1.56 \pm 0.02 \\
2.27 \pm 0.15 \\
5.65 \pm 0.83 \\
8.15 \pm 1.82 \\
9.91 \pm 1.43\end{array}$ \\
\hline
\end{tabular}

Concerning the phytoflagellates, the exponential phase of growth with respect to the control was significantly higher $(p<0.01$, Table 1$)$ for those algae exposed to the PAR and UVA treatments than for those algae exposed to UVB (Fig. 4 A). With respect to day factor, the $\mathrm{K}$ of the exponential phase of the phytoflagellates exposed to UVB treatments was significantly lower on the three days than for those exposed to UVA and PAR treatments (Table 1).

The UVB inhibition was higher at the beginning of exponential growth (with respect to PAR control) and decreased linearly $\left(\mathrm{R}^{2} 0.93\right)$ at the end of that phase (Fig. 4 B). For phytoflagellates and Navicula $s p$. a decrease in $\mathrm{K}$ values was observed during the first 24 hours only when they received UVB (Figs. 3 and 4 A). The results for the chl-a analyses are shown in Table 2. The statistical analysis of the exponential growth rate using these

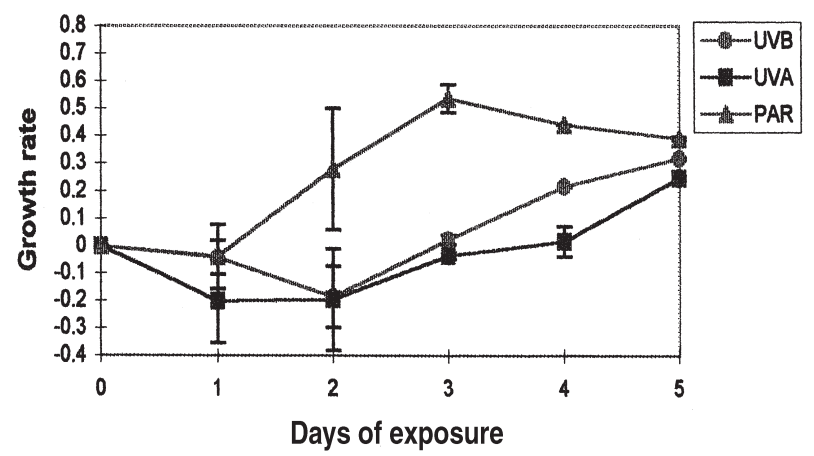

FIG. 5. - Growth rate using the cell number of the community when exposed to the natural solar radiation as a function of the exposition days. UVB represents those algae exposed to UVB + UVA + PAR, UVA those exposed to UVA + PAR and PAR, those exposed to PAR. Each point represents the mean with the standard error.
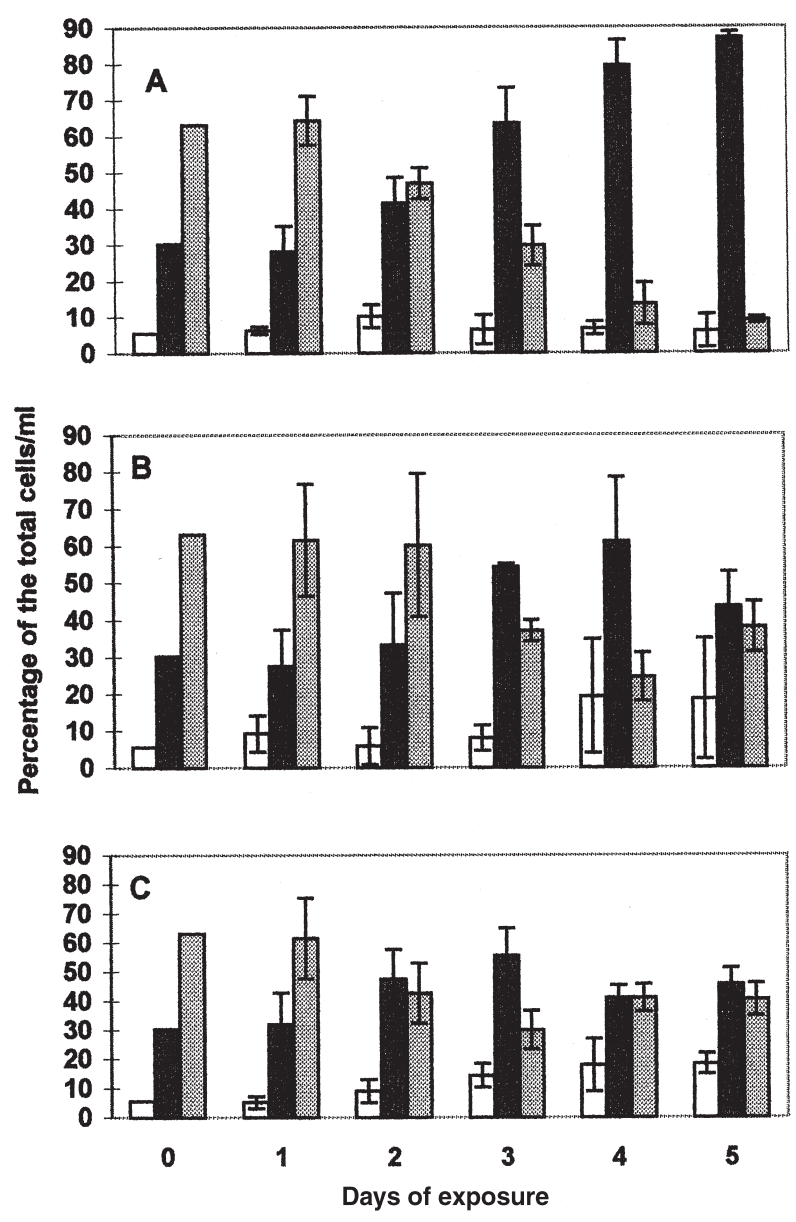

口pennate diatoms centric diatoms 娄flagellates

FIG. 6. - Relative abundance of each group of the community during the exposure days when exposed to: (A) UVB (UVB + UVA +PAR); (B) UVA (UVA+ PAR); (C) PAR.

data showed the same results as for the statistical analyses considering the cell number of algae per millilitre. 


\section{Experiment with the community}

Significant differences in K (Table 1) were found between the treatments including UVR and the PAR treatments (Fig. 5). UVB caused a decrease in K during the first 48 hours at the time the experience started. That period lasted 24 hours for UVA and PAR (Fig. 5).

The daily exposure of the community to UVB and UVA produced an inhibition of $220 \%$ and $560 \%$, respectively, at the beginning of the exponential phase. Both percentages decreased linearly to around $95 \%$ at the end of that exponential phase (day 3).

Marked changes in the relative abundance of the main taxonomic groups were observed using the PAR treatment as control. In the UVB treatment, there was a significant decrease $(\mathrm{p}<0.05)$ for the phytoflagellates, from approximately $65 \%$ on day 0 to $5 \%$ on day 5 . This contrasted with a significant increase $(\mathrm{p}<0.05)$ of around $60 \%$ in the abundance of the centric diatoms (Fig. 6). The pennate diatoms of the community did not show significant differences when the exposure days and treatments were analyzed (Fig. 6). The results for the chl-a analyses are shown in Table $2 \mathrm{~B}$. The statistical analysis of the exponential growth rate using these data showed the same results as when they were analyzed using the cell number of algae per millilitre.

\section{DISCUSSION}

The results of our experiences showed that the ultraviolet solar radiation might have produced deleterious effects upon the growth rate of some species in the phytoplanktonic populations of the Beagle Channel. It was evident from our data that the conditions we imposed upon these natural assemblages of phytoplankton represent the worst-case scenario since we were taking samples from their natural environment and exposing them to a radiation regime that they would encounter only when remaining within a few centimetres of the ocean surface. This was similar in many ways, however, to conditions which phytoplankton in near-surface waters would experience in the Beagle Channel when a well developed ozone hole is present, which would increase the flux of UV-B radiation dramatically (particularly at shorter UV-B wavelengths) beyond what they would normally encounter at that time of year. The rates at which phytoplankton cir- culates within the upper mixed layer (UML) are generally not known, but Denman and Gargett (1983) have estimated time scales ranging from 0.5 hours to hundreds of hours for a UML of 10 metres.

No inhibition was detected when diatoms (Navicula sp.) were exposed to UVB or UVA. In contrast, the phytoflagellates [Class Cryptophyceae] were inhibited by the UVB radiation (Fig. 4 A). This inhibition reached $180 \%$ and then decreased linearly $\left(\mathrm{R}^{2}\right.$ $0.93)$ to $100 \%$ at the end of the exponential growth rate (Fig. $4 \mathrm{~B}$ ) with respect to the PAR exponential phase. In order to explain why this percentage decreased as a function of time (days), the presence of antioxidant enzymes and the magnitude and efficiency of DNA repair mechanisms should be considered.

There was no inhibition of the growth rate by UVA (Fig. 4 A) on this class of phytoflagellate.

The daily exposure of the community to UVB and UVA produced an inhibition on the exponential phase of the growth rate (Fig. 5). These results are in agreement with those found in other studies that have been done in the Beagle Channel (Helbling et $a l .$, 1996). They showed an inhibition in the photosynthetic rate when the community was exposed to UVA and UVB for short periods of time (hours). In these cases the inhibition produced by UVA was also higher than that produced by UVB.

The average surface daily dose during community experiments was $15 \%$ higher than in monospecific culture experiments. This could be an explanation for the differences in the percentage of inhibition produced by UVB. An increase in the irradiance produced a significative increase on the phytoplankton inhibition (Helbling et al., 1996).

Considering the whole community, some taxonomic groups were more sensitive to the UVB radiation than others. There was no inhibition by the UVR on the pennate diatoms. The relative abundance was the same during all the exposure days and there were no statistical differences between treatments (Fig. 4 A-C). At the beginning of the experiment with the community, the percentage of centric diatoms was around $40 \%$ and of flagellates $45 \%$. This was the moment of maximum inhibition. On the fourth exposure day, when the inhibition was minor, these percentages changed to $80 \%$ and $13 \%$, respectively. This agrees with previous results of studies in Antarctic waters which indicate that phytoflagellates as a group are more sensitive to UVR as compared to diatoms (Helbling et al., 1994; Villafañe et al., 1995). 
The dinoflagellates probably died because of an inappropriate culture medium. There were no differences in any treatment and the percentage was zero on the third day of the experiment.

In order to explain the difference in relative abundance of the main taxonomic groups, one possible reason could be the different sensibility of the species that compose the sample. Previous studies (Karentz et al., 1991; Bothwell et al., 1993; Villafañe et al., 1995) have demonstrated that there is a large range of differential tolerance to UVB and UVA by different taxa. Some species were not adversely affected by the exposure to the full spectrum of wavelengths.

It was evident from our data that during the initial days of each experiment the cultures were adjusting to new conditions (Figs. 3-5). The algae were more sensitive to UV during lag-phase growth. The wide variation in tolerance to UVB in algae raises the obvious ecological implication that UVB may be an active factor for niche separation among microalgal species.

Our UV-treated algae were also exposed to UVA which is a contributor to photosynthetic inhibition in phytoplankton and inhibits the growth rates of at least some algae (Jokiel and York, 1984). An important consequence of this exposure is photoreactivation of UVB damage (Friedberg, 1985). UVA and shorter wavelengths of PAR also stimulate the production of UVB protective compounds (mycosporine-like amino acids [MAAs]) in many algal species (Carreto et al., 1990). Further studies should incorporate analysis of these compounds.

Our report is the first documentation of the effect of UVR on phytoplankton species of Subantarctic waters.

\section{REFERENCES}

Blumthaler, M. and W. Ambach. - 1990. Indication of increasing solar ultraviolet-B radiation flux in alpine regions. Science, 248: 206-208.

Bothwell, M.L., D. Sherbot, A.C. Roberge and R. Daley. - 1993. Influence of natural ultraviolet radiation on lotic periphytic diatom community growth, biomass accrual and species composition: short term vs. long term effects. J. Phycol., 29: 24-35.

Carreto, J.J., M.O. Carignan, G. Daleo and S.G. De Marco. - 1990 Occurrence of mycosporine-like aminoacids in the red tide dinoflagellate Alexandrium excavatum: UV-photoprotective compounds? J. Plankton Res., 12: 909-921.

Cullen, J.J., P.J. Neale and M.P. Lesser. - 1992. Biological weighting function for the inhibition of phytoplankton photosynthesis by ultraviolet radiation. Science, 258: 646-650.

Davidson, A.T. and H.J. Marchant. - 1994. Ultraviolet radiation in Antarctica: measurements and biological effects. Antarct. Res. Ser., 62: 187-205.

Denman, K.L. and A.E. Gargett. - 1983. Time and space scales of vertical mixing and advection of phytoplankton in the sea. Limnol. Oceanogr., 28: 801-815.

Friedberg, E.C. - 1985.- DNA Repair. W. H. Freeman and Co., New York.

Guillard, R.R. and J.H. Ryther. - 1962. Studies of marine planktonic diatoms. I. Cyclotella nana, Hustedt and Detonula contervacea Cleve. Can. J. Microbiol., 8: 229-239.

Helbling E.W., V. Villafañe, M. Ferrario and O. Holm-Hansen. 1992. Impact of natural ultraviolet radiation on rates of photosynthesis and on specific marine phytoplankton species. Mar. Ecol. Progr. Ser., 80: 89-100.

Helbling, E.W., V.E. Villafañe and O. Holm-Hansen. - 1994. Effects of ultraviolet radiation on Antarctic marine phytoplankton photosynthesis with particular attention to the influence of mixing. In: S. Weiler and P. Penhale (eds.): Ultraviolet Radiation in Antarctica: Measurements and Biological Effects, pp. 207-227. American Geophysical Union, Washington.

Helbling E.W., M.P. Hernando, O. Holm-Hansen and V. Villafañe. - 1996. Efectos de la radiación ultravioleta en el fitoplancton del Canal Beagle, Argentina. In: Comisión Organizadora XVI Jornadas de Ciencias del Mar (eds.): XVII Jornadas de Ciencias del Mar, pp. 149-150. Concepción, Chile.

Holm-Hansen, O., C.J. Lorenzen, R.W. Holmes and J.D.H. Stickland. - 1965. Fluorometric determination of chlorophyll. J. Cons. Int. Explor. Mer, 30: 3-15.

Holm-Hansen, O. and B. Riemann. - 1978. Chlorophyll a determination: improvements in methodology. Oikos, 30: 438-447.

Holm-Hansen, O., E.W. Helbling and D. Lubin. - 1993. Ultraviolet radiation in Antarctica: inhibition of primary production. Photochem. Photobiol., 58: 567-570.

Jitts, H.R., A. Morel and Y. Saijo. - 1976. The relation of oceanic primary production to available photosynthetic irradiance. Aust. J. Mar. Freshwater Res, 27: 411-434.

Jokiel, P.L. and R.H. York. - 1984. Importance of ultraviolet radiation in photoinhibition of microalgal growth. Limnol. Oceanogr., 29: 192-199.

Karentz, D., J.E. Cleaver and D.L. Mitchell. - 1991. Cell survival characteristics and molecular responses of Antarctic phytoplankton to ultraviolet-B radiation exposure. J. Phycol., 24: 326-341.

Lubin, D., J. Frederick, C. Booth, T. Lucas and D. Neuschuler. 1989. Measurement of enhanced springtime ultraviolet radiation at Palmer Station Antarctica. Geophys. Res. Lett., 16: 783785 .

Mitchell, B.G. - 1990. Action spectra of ultraviolet photoinhibition of Antarctic phytoplankton and a model of spectral diffuse attenuation coefficients. In: B.G. Mitchell, O. Holm-Hansen and I. Sobolev (eds.): Response of Marine Phytoplankton to Natural Variations in $U V-B$ Flux, pp. 1-10. Scripps Institution of Oceanography, La Jolla.

Neter, J. and W. Wasserman. - 1974. Applied Linear Statistical Models. Regression, Analysis of Variance, and Experimental Designs. Richard D. Irwin, Inc., Homewood Illinois.

Orce, L.V., N.A. San Roman, G. Rae, A. Paladini, J.C. Labraga, L.G. Buitrago, V.E. Villafañe and E.W. Helbling. - 1995. Latitudinal UV-PAR Monitoring Network in Argentina. Proc. WHO/WMO/NOAA/CIRES Conference: 20-34.

Orce, L.V., N. San Román, A. Paladini, J. Labraga and E. Helbling. - 1997. Multiple regression fit. Latitudinal UVR-PAR measurements in Argentina: extent of the 'ozone hole' Global and Planetary Change, 15: 113-121.

Smith, R.C. and K.S. Backer. - 1979. Penetration of UV-B and biologically effective dose-rates in natural waters. Photochem. Photobiol., 29: 322-323.

Smith, R.C. and K.S. Backer. - 1981. Optical properties of the clearest natural waters (200-800 nm). Appl. Opt., 20: 177-184.

Smith, R.C., B. Prezelin, K. Baker, R. Bidigare, N. Boucher, T. Coley, D. Karentz, S. MacIntyre, A. Matlick, D. Menzies, M. Ondrusek, Z. Wan and K.J. Waters. - 1992. Ozone depletion: ultraviolet radiation and phytoplankton biology in Antarctic waters. Science, 255: 952-959.

Steemann Nielsen, E. - 1964. On a complication in marine productivity work due to the influence of ultraviolet light. J. Cons. Cons. Int. Explor. Mer, 29: 130-135.

Villafañe, V.E., E.W. Helbling, O. Holm-Hansen and B. Chalker. 1995. Acclimatization of Antarctic natural phytoplankton assemblages when exposed to solar ultraviolet radiation. $J$. Plankton Res., 17: 2295-2306. 
Villafañe, V.E. and F. Reid. - 1995. Métodos de microscopia para la cuantificación del fitoplancton. In: K. Alveal, M.E. Ferrario, E. Olivera and E. Sar (eds.): Manual de Métodos Ficológicos, pp. 169-185. Univ. Concepción, Concepción, Chile. Watson, R. - 1988. Ozone Trends Panel. Executive Summary. NASA Report \# 1208, August. 